University of Nebraska - Lincoln

DigitalCommons@University of Nebraska - Lincoln

Publications, Agencies and Staff of the U.S.

Department of Commerce

U.S. Department of Commerce

2007

\title{
Pacific Salmon Extinctions: Quantifying Lost and Remaining Diversity
}

Richard G. Gustafson

National Marine Fisheries Service, rick.gustafson@noaa.gov

Robin Waples

NOAA, robin.waples@noaa.gov

James M. Myers

National Marine Fisheries Service

Laurie A. Weitkamp

National Marine Fisheries Service, laurie.weitkamp@noaa.gov

Gregory J. Bryant

National Marine Fisheries Service

See next page for additional authors

Follow this and additional works at: https://digitalcommons.unl.edu/usdeptcommercepub

Gustafson, Richard G.; Waples, Robin; Myers, James M.; Weitkamp, Laurie A.; Bryant, Gregory J.; Johnson, Orlay W.; and Hard, Jeffrey J., "Pacific Salmon Extinctions: Quantifying Lost and Remaining Diversity" (2007). Publications, Agencies and Staff of the U.S. Department of Commerce. 438.

https://digitalcommons.unl.edu/usdeptcommercepub/438

This Article is brought to you for free and open access by the U.S. Department of Commerce at DigitalCommons@University of Nebraska - Lincoln. It has been accepted for inclusion in Publications, Agencies and Staff of the U.S. Department of Commerce by an authorized administrator of DigitalCommons@University of Nebraska - Lincoln. 


\section{Authors}

Richard G. Gustafson, Robin Waples, James M. Myers, Laurie A. Weitkamp, Gregory J. Bryant, Orlay W. Johnson, and Jeffrey J. Hard 


\title{
Pacific Salmon Extinctions: Quantifying Lost and Remaining Diversity
}

\author{
RICHARD G. GUSTAFSON, ${ }^{*} \ddagger$ ROBIN S. WAPLES, ${ }^{*}$ JAMES M. MYERS, ${ }^{*}$ LAURIE A. WEITKAMP, \\ GREGORY J. BRYANT, $†$ ORLAY W. JOHNSON, ${ }^{*}$ AND JEFFREY J. HARD*
}

*National Marine Fisheries Service, Northwest Fisheries Science Center, 2725 Montlake Boulevard East, Seattle, WA 98112-2097, U.S.A.

†National Marine Fisheries Service, Southwest Region Protected Resources Division, 1655 Heindon Road, Arcata, CA 95521, U.S.A.

\begin{abstract}
Widespread population extirpations and the consequent loss of ecological, genetic, and life-bistory diversity can lead to extinction of evolutionarily significant units (ESUs) and species. We attempted to systematically enumerate extinct Pacific salmon populations and characterize lost ecological, life history, and genetic diversity types among six species of Pacific salmon (Chinook [Oncorhynchus tshawytscha], sockeye [O. nerka], cobo [O. kisutch], chum [O. keta], and pink salmon [O. gorbuscha] and steelbead trout [O. mykiss]) from the western contiguous United States. We estimated that, collectively, 29\% of nearly 1400 bistorical populations of these six species have been lost from the Pacific Northwest and California since Euro-American contact. Across all species there was a bighly significant difference in the proportion of population extinctions between coastal (0.14 extinct) and interior (0.55 extinct) regions. Sockeye salmon (which typically rely on lacustrine babitats for rearing) and stream-maturing Chinook salmon (which stay in freshwater for many months prior to spawning) had significantly higher proportional population losses than other species and maturation types. Aggregate losses of major ecological, life-history, and genetic biodiversity components across all species were estimated at 33\%, 15\%, and $27 \%$, respectively. Collectively, we believe these population extirpations represent a loss of between 16\% and 30\% of all bistorical ESUs in the study area. On the other hand, over two-thirds of historical Pacific salmon populations in this area persist, and considerable diversity remains at all scales. Because over one-third of the remaining populations belong to threatened or endangered species listed under the U.S. Endangered Species Act, it is apparent that a critical juncture bas been reached in efforts to preserve what remains of Pacific salmon diversity. It is also evident that persistence of existing, and evolution of future, diversity will depend on the ability of Pacific salmon to adapt to anthropogenically altered habitats.
\end{abstract}

Keywords: biodiversity, population extinction, salmon diversity, salmon life history

Extinciones de Salmón del Pacífico: Cuantificación de la Diversidad Perdida y la Remanente

Resumen: Las extirpaciones generalizadas de poblaciones y la consecuente pérdida de diversidad ecológica, genética y de bistoria natural puede llevar a la extinción de unidades evolutivamente significativas (UES) y especies. Intentamos enumerar sistemáticamente a las poblaciones extintas de salmón del Pacífico y caracterizar a los tipos de diversidad ecológica, de bistoria natural y genética de seis especies de salmón del Pacífico Oncorhynchus tshawytscha, O. nerka, O. kisutch, O. keta, $y$ O. gorbuscha; $y$ trucha O. mykiss en el occidente de Estados Unidos. Estimamos que, colectivamente, se ha perdido a 29\% de casi 1400 poblaciones bistóricas de estas seis especies en el Pacífico Noroeste y California desde la colonización europea. En todas las especies hubo una diferencia altamente significativa en la proporción de extinción de poblaciones entre regiones costeras $(0.14$ extintas) e interiores $(0.55$ extintas). O. nerka (que típicamente cría en hábitats lacustres) y O. tshawytscha (que permanece en agua dulce por muchos meses antes del desove) tuvieron pérdidas poblacionales significativamente mayores que las otras especies y tipos de maduración. Se estimó que las 
pérdidas agregadas de componentes mayores de la biodiversidad ecológica, de historia natural y genética en todas las especies fueron de 33\%, 15\% y 27\%, respectivamente. Colectivamente, consideramos que estas extirpaciones de poblaciones representan una pérdida entre 16\% y 30\% de todas las UES bistóricas en el área de estudio. Por otro lado, más de dos tercios de las poblaciones bistóricas de salmón del Pacífico persisten en esta área, y aun bay considerable diversidad en todas las escalas. Debido a que más de un tercio de las poblaciones restantes pertenecen a especies enlistadas como amenazadas o en peligro en el Acta de Especies en Peligro de E. U. A., es evidente que se ha llegado a una disyuntiva crítica en los esfuerzos para preservar lo que queda de la diversidad de salmón del Pacífico. También es evidente que la persistencia de la diversidad existente, y su futura evolución, dependerá de la habilidad del salmón del Pacífico para adaptarse a bábitats alterados antropogénicamente.

Palabras Clave: biodiversidad, diversidad de salmones, extinción de poblaciones, historia de vida de salmones

\section{Introduction}

Most assessments of extinction have focused on entire species (Ehrlich \& Daily 1993; Hobbs \& Mooney 1998); however, growing concern about loss of biodiversity at finer scales has fostered recent attempts to document population-level extinctions. For example, several metaanalyses have had geographic range shrinkage at the species level as an indirect proxy for the number of population extinctions on a global scale (Hughes et al. 1997): a subset of terrestrial mammals (Ceballos \& Ehrlich 2002) and British butterflies, birds, and plants (Thomas et al. 2004). Results of other analyses provide a partial list of extinct stocks of Pacific salmon in the western United States (Nehlsen et al. 1991) and quantify global amphibian population losses from 1950 to 1997 (Houlahan et al. 2000). Nevertheless, these analyses were generally not structured around a consistent biological definition of stock or population, and no attempts were made to examine losses of major components of diversity. Here we used a standardized definition of population (McElhany et al. 2001) to identify both extant and extinct Pacific salmon populations and estimated population losses by region and species since substantial Euro-American contact (approximately AD 1800 in the Pacific Northwest and AD 1770 in California). In addition, we characterized each population following the hierarchical matrix of salmon diversity first proposed by Waples et al. (2001) and assessed the magnitude of lost biodiversity in the form of major levels of ecological, life-history, and genetic diversity and extinct evolutionarily significant units (ESUs). Herein $\mathrm{Pa}$ cific salmon are Chinook (Oncorbynchus tshawytscha), sockeye (O. nerka), coho (O. kisutch), chum (O. keta), and pink salmon $(O$. gorbuscha) and the anadromous form of rainbow trout (commonly known as steelhead [O. mykiss]).

Our analyses were motivated by a recent characterization of biodiversity in extant Pacific salmon populations in the Pacific Northwest (Waples et al. 2001) and the realization that Pacific salmon no longer occur in upward of $40 \%$ of their historical freshwater range in the west- ern contiguous United States (National Research Council 1996). Waples et al. (2001) categorized Pacific salmon diversity on three major axes (ecology, life history, and biochemical genetics) and found positive correlations between the number of major ecological regions and the number of life history and genetic groups of individual species. These findings suggest that, in principle, the extent of ecological complexity in historical habitats occupied by extinct Pacific salmon populations can be used to estimate hierarchical levels of lost life history and genetic diversity.

Any attempt to assemble a comprehensive list of historical populations and ESUs of Pacific salmon is somewhat conjectural because many extirpations likely went unnoticed before initiation of biological surveys and extensive out-of-basin stocking practices may have either replaced native populations or resulted in extensive hybridization with nonindigenous fish.

Nonetheless, we have attempted to establish an appropriate historical baseline (Pauly 1995) of Pacific salmon diversity because this will help identify realistic and achievable targets for ongoing conservation efforts.

\section{Methods}

\section{Study Area}

We organized historical populations of Pacific salmon within the ecological regions described by Waples et al. (2001), with some expansion to accommodate areas that once supported anadromous Pacific salmon (Table 1; Figs. 1-4). These regions encompassed parts of Washington, Oregon, Idaho, Nevada, and California and portions of the Canadian Province of British Columbia that share transboundary ecological regions with U.S. salmon populations. The expanded list of ecological regions and their characteristics is available from http://www.nwfsc. noaa.gov/publications/displayallinfo.cfm?docmetadataid $=6570$. 
Table 1. Estimated number of extant and extinct (in parentheses) Pacific salmon populations for each species or maturation type and total number of populations extant and extinct (in parentheses) within each species, maturation type, region, and in the entire study area.

\begin{tabular}{|c|c|c|c|c|c|c|c|c|c|c|}
\hline Ecological region & \multicolumn{2}{|c|}{ Steelbead } & \multicolumn{2}{|c|}{ Chinook } & Sockeye & Cobo & Chum & Pink & Total & Extinct $(\%)$ \\
\hline A. Georgia Basin & $12(0)$ & $57(2)$ & $12(9)$ & $28(6)$ & $14(6)$ & $50(0)$ & $56(3)$ & $36(6)$ & $265(32)$ & 11 \\
\hline B. Coastal rainforest & $14(0)$ & $70(1)$ & $8(0)$ & $24(2)$ & $21(1)$ & $23(0)$ & $14(1)$ & $6(0)$ & $180(5)$ & 3 \\
\hline C. Northern coastal & $4(1)$ & $39(0)$ & $12(1)$ & $25(5)$ & - & $24(6)$ & $15(7)$ & - & $119(20)$ & 14 \\
\hline $\begin{array}{l}\text { D. Klamath Mountains } \\
\text { Province }\end{array}$ & $20(3)$ & $8(0)$ & $6(6)$ & $16(0)$ & - & $11(1)$ & $1(1)$ & $0(1)$ & $62(12)$ & 16 \\
\hline G. California Central Valley & - & $40(41)$ & $4(15)$ & $15(17)$ & - & $0(2)$ & $0(1)$ & $0(1)$ & $59(77)$ & 57 \\
\hline $\begin{array}{l}\text { H. Willamette and lower } \\
\text { Columbia }\end{array}$ & $6(2)$ & $18(5)$ & $8(9)$ & $15(2)$ & - & $12(7)$ & $3(8)$ & - & $62(33)$ & 35 \\
\hline I. Mid-Columbia River & $16(4)$ & - & $11(9)$ & - & $0(5)$ & $0(10)$ & $0(1)$ & - & 27 (29) & 52 \\
\hline J. Upper Columbia River & $11(8)$ & - & $10(15)$ & - & $2(5)$ & $0(10)$ & - & - & $23(38)$ & 62 \\
\hline K. Lower Snake River & $27(4)$ & - & $33(18)$ & - & $1(6)$ & $0(7)$ & - & - & $61(35)$ & 36 \\
\hline Extinct (\%) & 31 & 19 & 54 & 21 & 47 & 27 & 21 & 18 & 29 & \\
\hline
\end{tabular}

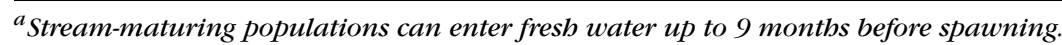

${ }^{b}$ Ocean-maturing populations are reproductively mature when they enter fresh water and generally spawn soon thereafter.

${ }^{c}$ These categories should not be confused with two major life-history types of Chinook salmon, termed stream type and ocean type (see Waples et al. 2001, 2004).

\section{Identification of Historical Populations}

To provide a consistent, quantitative framework for identifying populations, we adopted McElhany et al.'s (2000) "demographically independent population" concept, which defines an independent population as "any collection of one or more local breeding units whose population dynamics or extinction risk over a 100 -year time period are not substantially altered by exchanges of individuals with other populations" (McElhany et al. 2000).

Within the U.S. portion of our study area, 51 extant ESUs of the six species have been identified formally, based on consideration of ecological, life history, and genetic data (Waples 1991, 1995), and about half of these are listed as threatened or endangered "species" under the U.S. Endangered Species Act (ESA) (see http://www.nwr. noaa.gov/ESA-Salmon-Listings/Index.cfm). Technical recovery teams (TRTs), composed of scientists from inside and outside government and formed to develop biological delisting criteria and standards for measuring recovery efforts for Pacific salmon, have used the McElhany et al. (2000) framework to identify existing and in some cases extinct "functionally independent" populations that makeup listed ESUs (Lindley et al. 2004, 2006; Bjorkstedt et al. 2005; Boughton et al. 2006; Myers et al. 2006; Ruckelshaus et al. 2006; Williams et al. 2006). In most cases we incorporated these TRT-identified populations (which accounted for $35 \%$ of the total) into our analysis.

Nevertheless, the TRTs did not identify populations in areas where particular salmon species are extinct or not listed under the ESA. In those areas we used five general criteria to identify extinct populations: (1) documented historical presence, (2) basin area (square kilometers) and structure (e.g., barrier waterfalls), (3) environmental characteristics, (4) temporal isolation (different run or spawn timing), and (5) geographic isolation (e.g., distance between high-elevation refuges for adult streammaturing fish). To identify extant populations, we used the above criteria and known genetic attributes, phenotypic characteristics, dispersal distances and rates, and population dynamics and size. In areas where salmon no longer occur, we first examined primary (e.g., traditional knowledge, archaeological reports, and accounts of early explorers, surveyors, fur trappers, missionaries, and settlers) and secondary (agency fisheries reports, journal articles, and ethnographic reports) sources to identify historical distributions of Pacific salmon in the Pacific Northwest and California prior to Euro-American contact. A list of these biogeographical sources is available from http://www.nwfsc.noaa.gov/publications/displayallinfo. cfm?docmetadataid $=6570$. We then analyzed watersheds within each species' historical distribution for potential population-isolating mechanisms, such as seasonal or complete migration barriers, ecologically distinctive tributary habitats, and distance between potential spawning aggregates.

We used basin area, and lake-rearing area in the case of sockeye salmon, as additional criteria for establishing historical population boundaries. Lindley et al. (2004) and Myers et al. (2006) articulated a "geographic template" 


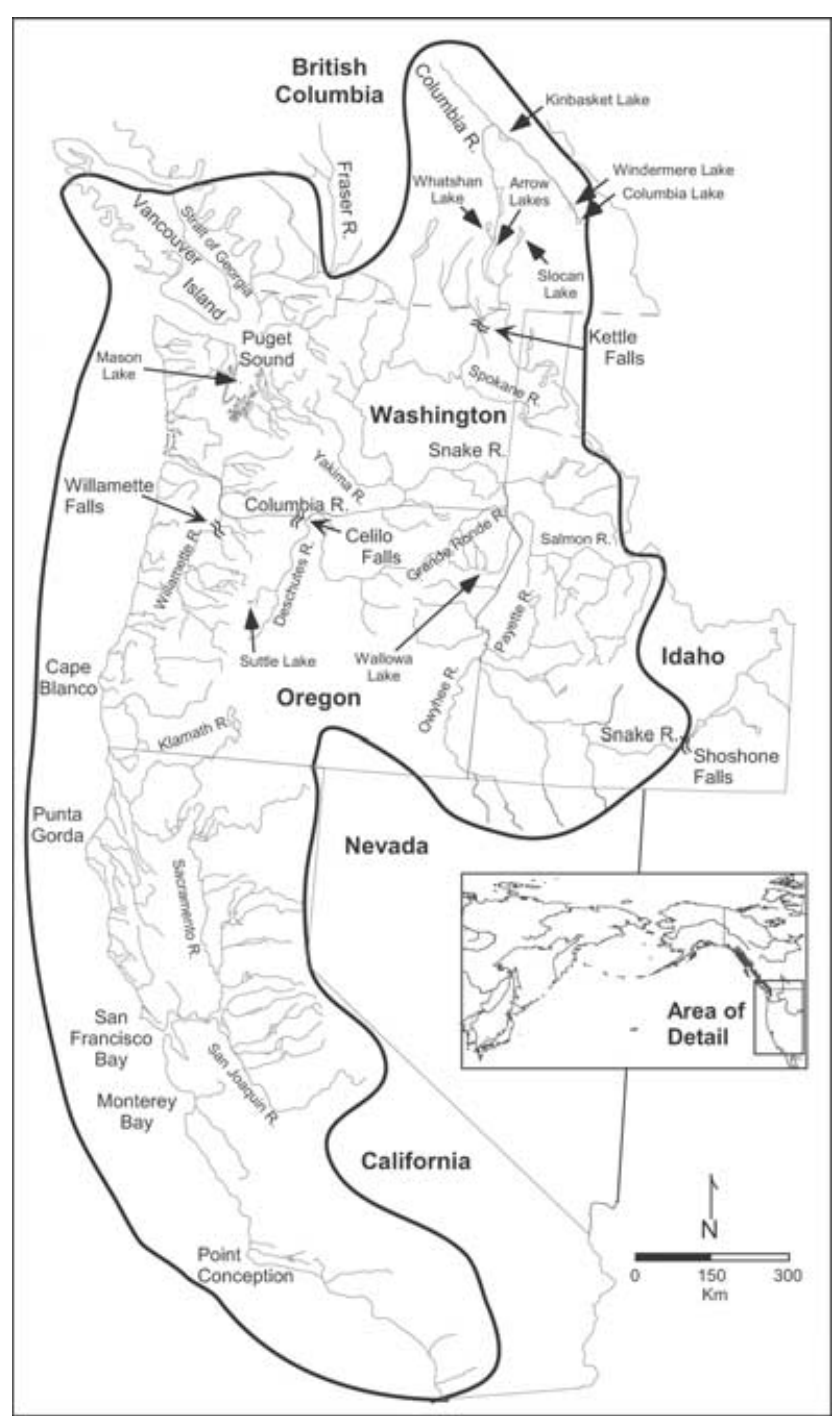

Figure 1. Major geographic features and river basins within the study area, which encompassed parts of Washington, Oregon, Idabo, Nevada, California, and portions of the Canadian province of British Columbia.

model (see Myers et al. [2006] for details), which uses the basin area (a proxy for habitat area) used by extant Chinook salmon populations to establish a minimum basin size that could support a demographically independent population under variable environmental conditions. We examined watersheds containing extant independent populations identified by the TRTs to establish minimum basin-area guidelines for populations of each species and maturation type throughout our study area. Due to life history and habitat differences, these guidelines differed both regionally and taxonomically, and were used most often to combine two or more spawning aggregates into a single putative independent population when their constituent basin areas were less than the guidelines.

\section{Extinction Definition}

We classified populations as extinct or extirpated if the population no longer occurs in its historical habitat, the population has been replaced by a nonindigenous population, or the anadromous component of the population no longer exists, even if a potential remnant gene pool of resident fish-represented by kokanee (in the case of sockeye salmon) or rainbow trout (in the case of steelhead) still survives above human-made barriers to anadromy. In cases where multiple populations historically existed within a large river basin but can no longer access historical spawning habitat and consequently spawn together as one present-day homogenized assemblage (e.g., Sacramento River winter-run Chinook salmon), we considered only a single extant population to exist.

\section{Hierarchical Organization of Biodiversity}

We used criteria explained in detail in Waples et al. (2001) to assign each population to three hierarchical levels (I, II, III) of ecological, life-history, and genetic diversity, with level I representing major groups and levels II and III subgroups nested within the major groups. We used data from historical studies (e.g., a 4-year life cycle in some upper Columbia River coho salmon [Marr 1943]) to identify extinct life-history diversity characteristics. We also used information about ecological features of the populations' lost habitat to identify selective regimes that may have promoted adaptively important life-history characters and genetic differentiation. Because life history and genetic information is generally lacking for extinct populations, we relied heavily upon comparison with extant populations, whose levels of life history and genetic diversity have been evaluated, to characterize likely historical hierarchical levels of diversity for extinct populations. Hierarchical diversity characteristics and a detailed list of extant and extinct populations and their hierarchical diversity assignments are available from http://www.nwfsc.noaa.gov/publications/displayallinfo. cfm?docmetadataid $=6570$.

We limited our analyses to level-I diversity categories, with one exception: both Chinook salmon and steelhead have two adult maturation strategies (designated as stream- and ocean-maturing in reference to the location where the final maturation of adults takes place). Because these life-history types reflect parallel evolution, they were recognized as a level-III diversity category (Waples et al. 2001). Nevertheless, because the stream-maturing life-history strategy makes these populations much more vulnerable to anthropogenic threats, we compiled separate extinction data for the two types.

\section{Analysis}

To test for differences in the proportion of population extinctions among ecological regions and among species 

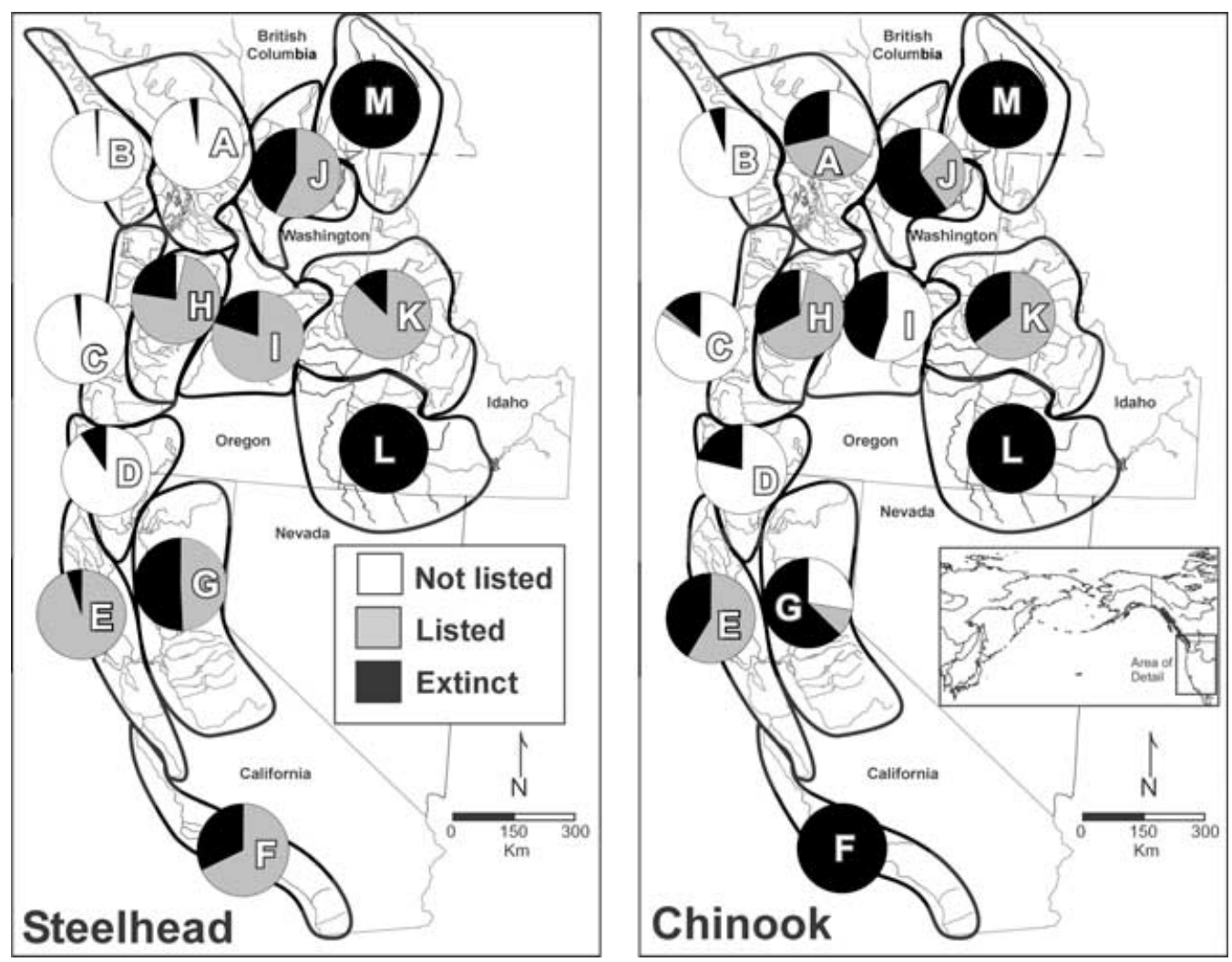

Figure 2. The relative proportion of Chinook salmon and steelhead populations within each historically occupied ecological region (uppercase letters defined in Table 1) that are extinct, extant but included in evolutionarily significant units listed as threatened or endangered under the U.S. Endangered Species Act (ESA), or extant but not listed under the ESA.

and maturation types, we used paired $Z$ test comparisons (Zar 1999) in SigmaStat for Windows (version 3.11, Systat Software, San Jose, California) corrected for multiple tests with the sequential Bonferroni method. When testing differences between proportions, the null hypothesis was that the two population proportions are equal.

\section{Identification of Historical ESUs}

We used available information for extant and extinct populations and inferences based on genetic, ecological, and life-history characteristics common to existing Pacific salmon ESUs to provisionally identify historical ESUs that no longer exist. To assist in these evaluations, for each putative historical ESU we posed two questions to TRT members with knowledge about historical conditions in their regions of expertise: (1) How definitive is the evidence for the species' persistent historical presence in the area? and (2) Assuming that the species was persistently present historically, were historical populations in these areas biologically distinctive? For each question respondents were asked to categorize their answers as doubtful, possible, or probable. Based on these results, we classified the putative extinct ESUs as either likely (probable answer to both questions 1 and 2) or possible (one prob- able answer and one possible answer). We did not define current or extinct ESUs within Canadian portions of our study area, with the exception of the headwaters of the transboundary Columbia River.

\section{Results}

\section{Population Extinctions by Area}

Nearly 1400 Pacific salmon populations occurred historically in the study area, and an estimated $29 \%$ have gone extinct since substantial Euro-American contact (Table 1). We consider this estimate conservative because many populations were lost before their existence was recognized or recorded. In addition, many populations classified as extant have been highly modified through human activities, particularly stock transfers, and maintain few of their historical characteristics. Other populations, although extinct in their native habitat, exist as remnants below impassable dams or in hatchery culture but are still considered extant.

Each species has been lost from a minimum of two, and a maximum of five, major ecological regions. Overall, six species no longer occur in about one-third of the regions 

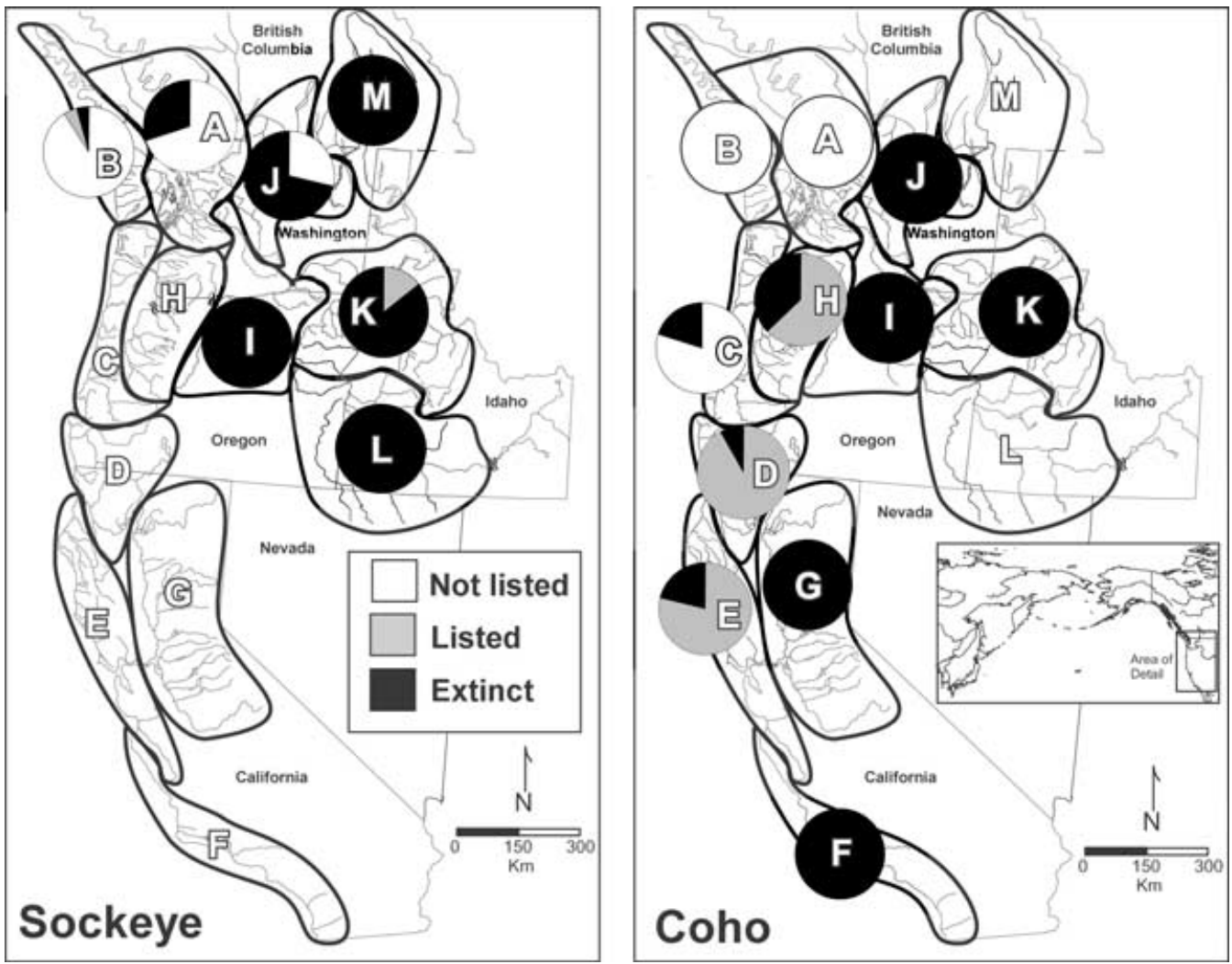

Figure 3. The relative proportion of sockeye and coho salmon populations within each bistorically occupied ecological region (uppercase letters defined in Table 1) that are extinct, extant but included in evolutionarily significant units listed as threatened or endangered under the U.S. Endangered Species Act (ESA), or extant but not listed under the ESA.

they formerly occupied (Table 1; Figs. 2-4). Patterns of population extinction within the 13 major ecological regions in our study area were strongly biased geographically (Table 1 ; Figs. 2-4). The estimated proportion of extinct historical populations was relatively low in coastal drainages from Vancouver Island to northern California $(\leq 20 \%)$ but increased dramatically in southern California (35\%), the California Central Valley (57\%), and the interior Columbia River Basin (35-62\% in areas still accessible to Pacific salmon) (Table 1). Comparisons across the 13 ecological regions indicated that the Coastal Rainforest (area B) had a significantly lower proportion of population loss than any other region (12 paired $Z$ tests, $Z \geq$ $3.1, p<0.003$ ). Conversely, upper Snake River (area L) and Columbia River headwaters (area M) had significantly greater proportional population losses than all other regions (22 paired $Z$ tests, $Z \geq 3.4, p<0.001$ ) (Table 1 ; Figs. 2-3). Furthermore, there were highly significant differences in the proportion of population extinctions between combined data for coastal (areas A-F, $n=862,0.14$ extinct) and interior (areas G-M, $n=521,0.55$ extinct) regions $(Z=16.5, p<0.001)$ and between northern coastal (areas A-C, $n=621,0.09$ extinct) and southern coastal (areas D-F, $n=241,0.25$ extinct) regions $(Z=5.9, p<$ $0.001)$.
Population Extinctions by Species and Major Maturation Type

Extinctions were also nonrandom with respect to species and major maturation types (Table 1). Coho salmon once occupied a range almost as large as that of Chinook salmon and steelhead, which historically occupied all ecological regions, but native coho salmon populations have disappeared from large portions of California and the Columbia River basin (Table 1; Fig. 3). Likewise, almost half of historical lacustrine sockeye salmon populations have been lost (Table 1; Fig. 3). At the other extreme, pink and chum salmon had relatively low levels of population extinction (18 and 21\%, respectively; Table 1; Fig. 4).

Comparisons among species and major maturation types of Pacific salmon indicated that sockeye and streammaturing Chinook salmon had statistically similar proportional population losses $(Z=0.9, p=0.354)$, but both sockeye (six paired $Z$ tests, $Z \geq 2.2, p \leq 0.028$ ) and stream-maturing Chinook salmon (six paired $Z$ tests, $Z \geq 4.5, p<0.001$ ) experienced a significantly greater proportion of population extinctions than other Pacific salmon species or maturation types. Stream-maturing steelhead had significantly more proportional population losses than ocean-maturing steelhead $(Z=3.0, p$ $=0.003$ ), and stream-maturing Chinook salmon had a 

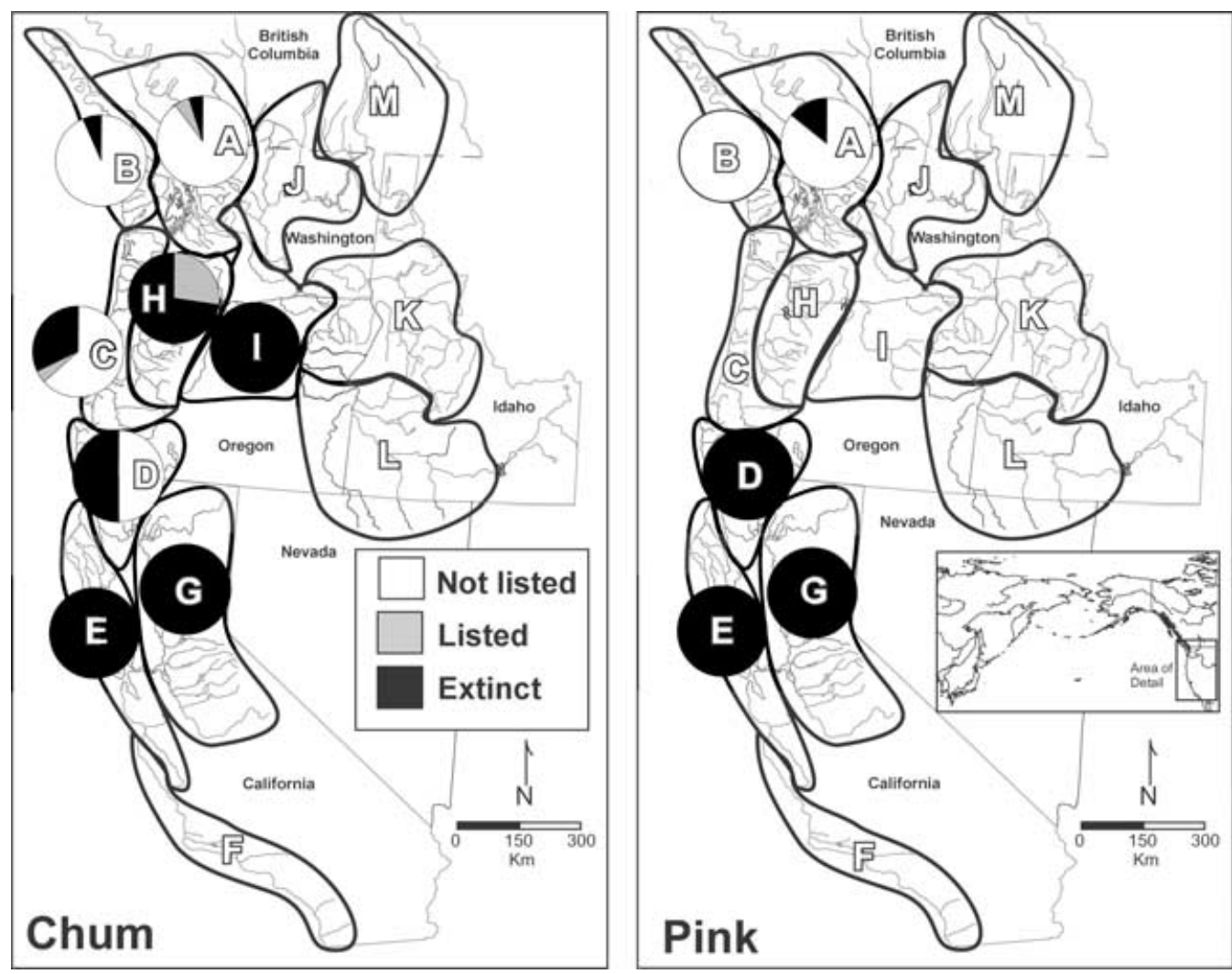

Figure 4. The relative proportion of pink and chum salmon populations within each historically occupied ecological region (uppercase letters defined in Table 1) that are extinct, extant but included in evolutionarily significant units listed as threatened or endangered under the U.S. Endangered Species Act (ESA), or extant but not listed under the ESA.

significantly higher proportion of population losses than ocean-maturing Chinook salmon $(Z=6.6, p<0.001)$.

\section{Historical Diversity Losses}

The loss of major genetic groups (27\%) was nearly as high as extirpation from ecological regions (33\%), but the loss of major life-history types was less extensive (an estimated 15\%) and perhaps confined to two species (chum and coho salmon) (Table 2). Overall loss of major genetic diversity was disproportionately attributed to sockeye salmon (over $75 \%$ of the total), whereas no extinct level-I genetic diversity units were identified for steelhead or Chinook salmon (Table 2). However, uncertainties associated with assigning biodiversity characters to extinct populations might have resulted in an artificially low number of extinct level-I life history and genetic categories.

\section{Historical ESUs}

Several Pacific salmon species no longer occur across entire ecological regions that were historically occupied, including all steelhead and Chinook and sockeye salmon in the upper Snake River (area L) and Columbia River headwaters (area M) and all coho salmon in the mid-Columbia
River (area I), upper Columbia River (area J), and lower Snake River (area K) (Table 1; Figs. 2 \& 3). The geographical extent of lost habitats and populations in each of these areas is similar to what constitutes an ESU for extant Pacific salmon species.

We identified a group of coho salmon populations and two groups of both Chinook salmon and steelhead that each represented at least one "certain" extinct ESU

Table 2. Estimated number of extant and extinct (in parentheses) major (level-I) diversity categories of Pacific salmon in the entire study area and number of existing (and range of possibly extinct) salmon ESUs ${ }^{a}$ in the mainland western United States.

\begin{tabular}{lcccc}
\hline Species & Ecology & Life bistory & Genetic & ESUs $^{b}$ \\
\hline Steelhead & $11(2)$ & $7(0)$ & $7(0)$ & $15(2-3)$ \\
Chinook salmon & $10(3)$ & $7(0)$ & $10(0)$ & $17(2-3)$ \\
Sockeye salmon & $4(3)$ & $6(0)$ & $23(13)$ & $7(5-8)$ \\
Coho salmon & $6(5)$ & $1(2)$ & $2(2)$ & $6(1-4)$ \\
Chum salmon & $5(3)$ & $1(2)$ & $2(1)$ & $4(0-2)$ \\
Pink salmon & $2(3)$ & $1(0)$ & $2(1)$ & $2(0-2)$ \\
Total & $38(19)$ & $23(4)$ & $46(17)$ & $51(10-22)$ \\
Extinct (\%) & 33 & 15 & 27 & $16-30$ \\
\hline
\end{tabular}

\footnotetext{
${ }^{a}$ Evolutionarily significant unit.

${ }^{b}$ Existing ESUs were formally identified; estimates of extinct ESUs are conjectural (see Table 3).
} 
Table 3. Extinct groups of Pacific salmon that might have represented historical ESUs. ${ }^{a}$

\begin{tabular}{|c|c|c|c|c|}
\hline Species & Proposed extinct ESUs & $\begin{array}{l}\text { Historical presence/ } \\
\text { distinctiveness }^{b}\end{array}$ & $\begin{array}{c}E S U \\
\text { likelibood }\end{array}$ & $\begin{array}{l}\text { Number of } \\
\text { extinct ESUs }\end{array}$ \\
\hline Steelhead & $\begin{array}{l}\text { Columbia River headwaters } \\
\text { upper Snake River } \\
\text { San Joaquin River }{ }^{c}\end{array}$ & $\begin{array}{l}+/++ \\
++/++ \\
++/++\end{array}$ & $\begin{array}{l}\text { possible } \\
\text { likely } \\
\text { likely }\end{array}$ & $2-3$ \\
\hline Chinook salmon & $\begin{array}{l}\text { Columbia River headwaters spring run } \\
\text { upper Snake River spring run } \\
\text { San Joaquin River spring run }\end{array}$ & $\begin{array}{l}++/++ \\
++/++ \\
++/+\end{array}$ & $\begin{array}{l}\text { likely } \\
\text { likely } \\
\text { possible }\end{array}$ & $2-3$ \\
\hline Sockeye salmon & $\begin{array}{l}\text { Arrow Lakes / Whatshan Lake } \\
\text { Slocan Lake }^{c} \\
\text { Columbia / Windermere/ Kinbasket lakes }^{c} \\
\text { Payette River }^{c} \\
\text { Wallowa Lake }^{c} \\
\text { Suttle Lake (Deschutes River, Oregon) }{ }^{c} \\
\text { Yakima River }^{c} \\
\text { Mason Lake (Puget Sound) }^{c}\end{array}$ & $\begin{array}{l}++/++ \\
++/+ \\
+/++ \\
++/++ \\
++/++ \\
++/++ \\
++/++ \\
+/+\end{array}$ & $\begin{array}{l}\text { likely } \\
\text { possible } \\
\text { possible } \\
\text { likely } \\
\text { likely } \\
\text { likely } \\
\text { likely } \\
\text { possible }\end{array}$ & $5-8$ \\
\hline Coho salmon & $\begin{array}{l}\text { upper Columbia River } \\
\text { Snake River } \\
\text { mid-Columbia River } \\
\text { Sacramento River }\end{array}$ & $\begin{array}{l}++/+ \\
++/+ \\
++/+ \\
+/++\end{array}$ & $\begin{array}{l}\text { possible } \\
\text { possible } \\
\text { possible } \\
\text { possible }\end{array}$ & $1-4^{d}$ \\
\hline Chum salmon & $\begin{array}{l}\text { southern Oregon / California coast } \\
\text { Sacramento River }\end{array}$ & $\begin{array}{l}+/+ \\
+/+\end{array}$ & $\begin{array}{l}\text { possible } \\
\text { possible }\end{array}$ & $0-2$ \\
\hline Pink salmon & $\begin{array}{l}\text { southern Oregon / California coast } \\
\text { Sacramento River }\end{array}$ & $\begin{array}{l}+/+ \\
+/+\end{array}$ & $\begin{array}{l}\text { possible } \\
\text { possible }\end{array}$ & $0-2$ \\
\hline
\end{tabular}

${ }^{a}$ Evolutionarily significant unit.

${ }^{b}$ Historical presence and biological distinctiveness, respectively, rated as either well documented $(++)$ or conjectural $(+)$.

${ }^{c}$ See Fig. 1.

${ }^{d}$ Coho salmon in the interior Columbia River basin formed at least one certain ESU that is now extinct because coho salmon that historically spawned east of the Cascade Mountains were not considered part of the extant lower Columbia River coho salmon ESU (Weitkamp et al. 1995).

and five populations of sockeye salmon that represented "likely" extinct ESUs (Table 3). In addition, 12 "possible" extinct ESUs were recognized throughout the study area ( 1 steelhead and 1 Chinook, 3 sockeye, 3 coho, 2 chum, and 2 pink salmon) (Table 3). Each of these proposed extinct ESUs should be considered conjectural and subject to modification based on more formal analyses and new information (e.g., retrospective genetic analyses of archived specimens). Nevertheless, if our proposed ESU structure is correct, between $16 \%$ and $30 \%$ of all historical ESUs (and perhaps at least one in each species) has been lost since Euro-American contact (Tables 2-3).

\section{Discussion}

\section{Patterns of Population Loss}

Our findings of lower proportional population losses in the Coastal Rainforest (area B) and higher proportional population losses in interior versus coastal regions and in southern versus northern coastal regions mirror the outcome of previous Pacific salmon status assessments (National Research Council 1996). These patterns can be attributed to a myriad of causes including differences in regional distribution of species or maturation types, regional differences in human activities (e.g., dam-building and land-use practices), and perhaps differing regional impacts of climate change (National Research Council 1996). Greater proportional population losses in the upper Snake River (area L) and Columbia River headwaters (area M) compared with all other regions were expected given that all historical anadromous populations were extirpated from these regions following installation of impassable dams.

The documented loss of all indigenous populations of coho salmon in the entire interior Columbia River basin east of the Cascade Mountains, where steelhead and Chinook salmon still persist, demonstrates the vulnerability of this species to extinction over large geographic areas (Table 1). Coho salmon may be particularly at risk due to their lengthy ( $>1$ year) juvenile residence in freshwater (making them vulnerable to perturbations of freshwater habitat) and a nearly fixed 3-year life cycle (providing less of a buffer against year-class failure than most other salmon species). Sockeye salmon are also particularly vulnerable, no doubt a result of that species' almost exclusive dependence for juvenile rearing on lake habitats, which have often been blocked by impassable dams. The low overall number of pink and chum salmon population 
extinctions can be attributed to the fact that the majority of these historical populations occurred in northern coastal portions of our study area, where overall extinction rates were relatively low (Table 1; Fig. 4) and to these species' short juvenile residence in freshwater $(<1-$ 2 months). On the other hand, stream-maturing steelhead and Chinook salmon (which may enter fresh water up to nine months before spawning) had significantly more population losses than their ocean-maturing counterparts (which are reproductively mature when they enter fresh water and generally spawn soon thereafter) (Table 1). Higher losses of stream-maturing populations are likely due to widespread loss of crucial high-elevation (generally $>500 \mathrm{~m}$ ) holding habitats and to their lengthy exposure to a host of risk factors during the prespawning holding period.

\section{Historical Diversity Losses}

Extinction of all coho and chum salmon populations in the interior Sacramento and Columbia River basins has resulted in the loss of a major life-history type for each species in both basins (Tables 1 \& 4). Coho and chum salmon that spawned east of the Cascade Mountains in the Columbia River basin would have had an unusually extensive freshwater migration (longer than any other coho and chum salmon populations in the study area), and Sacramento River populations of either species would have had unique adaptations for survival in the Central Valley of California (Fig. 1). Sockeye salmon account for over $75 \%$ of the lost major genetic units of Pacific salmon (Table 2), which is likely a result of the discontinuous occurrence of lake habitats suitable for sockeye rearing; a resulting high degree of reproductive isolation that has led to strong genetic differentiation and local adaptations (Burgner 1991; Wood 1995); and the proliferation of human-made dams that block anadromous access to most historical lake habitats.

As emphasized in Waples et al. (2001), we would expect there to be a strong relationship and interaction between the three major axes of intraspecific diversity: ecology, life history, and genetics. Our estimates of extinction of life history and genetic diversity rely in part on our perceptions of historical levels of ecological complexity; therefore, some overlap across axes of diversity was inevitable. Conclusions based on our estimates of lost diversity should also be tempered by uncertainty in reconstructing life-history traits of extinct populations, but the lower estimated rate of loss of major life-history groups compared with ecological and genetic diversity losses probably can be attributed in part to the phenotypic plasticity of Pacific salmon, which evolved in response to natural selection operating in heterogeneous environments (Thompson 1991). Although the failure of most stock transfers for Pacific salmon (Withler 1982;
Wood 1995) indicates that in general local populations are not ecologically exchangeable (Crandall et al. 2000), there is evidence from salmonid fishes (Bernatchez et al. 1996; Taylor et al. 1996; Waples et al. 2004) and other species (Schluter \& Nagel 1995) that parallel life-history traits can evolve independently in different lineages.

\section{Historical ESUs}

The 10 extinct groups of Pacific salmon that represented either certain or likely historical ESUs were all located in either the San Joaquin or interior Columbia river basins, and half of these were Columbia River sockeye salmon that occupied tributary lake habitats (Table 3; Fig. 1). The same factors that in general give lacustrine sockeye salmon a finer-scale genetic structure than other salmon species also translate into a finer-scale ESU structure (Waples et al. 2001), which in turn may put ESUs of this species at a greater risk of extinction.

The five other certain or likely extinct ESUs included one coho salmon and two each of Chinook salmon and steelhead (Table 3). Given that current Chinook salmon and steelhead in the interior Columbia River basin are distinctive enough to form ESUs separate from those in coastal areas and in the lower river and that extant coho salmon from the interior Fraser River in British Columbia are strongly differentiated genetically from lower Fraser River populations (Small et al. 1998), it is almost certain that extinct coho salmon populations that once ranged to at least the Spokane and Grande Ronde rivers in the interior Columbia River basin constituted one, and perhaps as many as three, historical ESUs (Tables $1 \& 3$; Fig. 1). In addition, the differences in ecological characteristics between the forested mountain rivers of central Idaho and northeastern Oregon and southeastern Washington (the area occupied by extant steelhead and spring- and summer-run Chinook salmon ESUs) and the desert basins of the upper Snake River upstream of the Owyhee River suggest that historical steelhead and spring-run Chinook salmon populations in this desert region would also have constituted distinct ESUs that are both now extinct (Table 3; Fig. 1).

Previous status assessments of steelhead (National Marine Fisheries Service 1997) and spring-run Chinook salmon (Myers et al. 1998) concluded that, historically, an ESU of each species may have occurred in California's San Joaquin River (Table 3; Fig. 1). Historical spring-run Chinook salmon and steelhead spawning and rearing areas in the upper reaches of the San Joaquin River were ecologically very distinct from those in the Sacramento River basin. Geographically, there was ample opportunity for reproductive isolation of San Joaquin River steelhead and spring-run Chinook salmon from conspecific populations in the Sacramento River. The presence of three subspecies of resident $O$. mykiss in the system is additional evidence 
of historical opportunities for differentiation of salmonids (Behnke 1992).

\section{Conclusions}

Pacific salmon population diversity has evolved in concert with dynamic oceanic and freshwater environmental templates. Maintenance of this diversity (at all scales) requires conservation of populations within their unique habitats (Healey \& Prince 1995). Nevertheless, many of the selective forces (e.g., seasonal streamflows, habitat complexity) that helped shape this myriad diversity have been altered profoundly by anthropogenic factors (habitat degradation, blockage of migratory routes, water withdrawals, harvest, introduction of exotic species, diseases, pollution, and competition and hybridization with hatchery salmon) (National Research Council 1996). In addition, climatic changes in the Pacific Northwest (Mote 2003a, b) are already altering selection pressures for salmon in both freshwater (Peterson \& Kitchell 2001; Hampton et al. 2006) and oceanic realms (Welch et al. 1998). Particularly troubling are high diversity losses in some geographic areas and the large fraction of remaining populations that currently face substantial extinction risk (proportion of ESA-listed populations represented in Figs. 2-4).

To persist in this area, Pacific salmon populations will have to express continued evolutionary adaptability to anthropogenically altered ecosystems. Fortunately, our analyses indicate that Pacific salmon in this region retain substantial evolvability as demonstrated by the persistence of over two-thirds of historical populations (Table 1) and substantial levels of biodiversity (Table 2)testimony to the past resilience of these species despite extensive anthropogenic changes. Evidence of ongoing adaptability can be found in reports of Pacific salmon spawning and persisting in cool water below dams that block access to their native spawning habitat (Williams \& Williams 1991; Dauble et al. 1999) and in the earlier arrival timing (Quinn \& Adams 1996) and faster upriver travel times (Quinn et al. 1997) of sockeye salmon in response to decreasing flow and increasing temperature over the last several decades in the Columbia River.

The TRTs include interpopulation diversity as one of four key characteristics in their evaluations of withinESU population viability and emphasize that preservation of populations representative of major historical levels of diversity are likely prerequisites for an ESU to reach sustainable status and to adapt to future environmental changes (McElhany et al. 2000, 2006). Likewise, studies of salmon in more pristine areas (e.g., Hilborn et al. 2003) suggest that historical levels of salmon abundance in our study area were probably not sustainable without the biocomplexity and resiliency inherent within an aggregate of populations adapted to local conditions.
Although the ESU remains a pragmatic and effective tool for characterizing diversity and assessing extinction risk on a broad scale, viability analyses and conservation actions are normally undertaken at smaller scales (McElhany et al. 2000). Here it is apparent that to preserve biodiversity at multiple scales in wild Pacific salmon, both the local population and its habitat (freshwater and marine) must become the basic unit of conservation. These tenets echo Aldo Leopold's (1953) "keep every cog and wheel" philosophy, which may still be the best general strategy for conserving biodiversity in an uncertain world. It would also be prudent to attempt to identify components of salmon biodiversity that will be most likely to persist and adapt in dynamic habitats and hence might represent geminate evolutionary units (Bowen 1998).

\section{Acknowledgments}

We thank M. J. Ford for advice and comments on the manuscript and P. J. Busby, P. W. Lawson, S. Lindley, M. M. McClure, P. McElhany, M. H. Ruckelshaus, and T. C. Wainwright for comments on extinct populations and ESUs. The status review and TRT reports that provided much of the data for these analyses benefited from input and collaboration by many other scientists, many of whom contributed unpublished data or analyses and are acknowledged therein. This is a scientific report. It does not represent or set policy for the U.S. National Marine Fisheries Service or National Oceanic and Atmospheric Administration, regardless of whether any statements contained herein may appear to do so.

\section{Literature Cited}

Behnke, R. J. 1992. Native trout of western North America. Monograph 6. American Fisheries Society, Bethesda, Maryland.

Bernatchez, L., J. A. Vuorinen, R. A. Bodaly, and J. J. Dodson. 1996. Genetic evidence for reproductive isolation and multiple origins of sympatric trophic ecotypes of whitefish (Coregonus). Evolution 50:624-635.

Bjorkstedt, E. P., B. C. Spence, J. C. Garza, D. G. Hankin, D. Fuller, W. E. Jones, J. J. Smith, and R. Macedo. 2005. An analysis of historical population structure for evolutionarily significant units of Chinook salmon, coho salmon, and steelhead in the North-Central California Coast Recovery Domain. Technical memorandum NMFS-SWFSC382. National Marine Fisheries Service, Southwest Fisheries Science Center, Santa Cruz, California.

Boughton, D. A., et al. 2006. Steelhead of the south-central/southern California Coast: population characterization for recovery planning. Technical memorandum NMFS-SWFSC-394. National Marine Fisheries Service, Southwest Fisheries Science Center, Santa Cruz, California.

Bowen, B. W. 1998. What is wrong with ESUs? The gap between evolutionary theory and conservation principles. Journal of Shellfish Research 17:1355-1358.

Burgner, R. L. 1991. Life history of sockeye salmon Oncorbynchus nerka. Pages 3-117 in C. Groot and L. Margolis, editors. Pacific 
salmon life histories. University of British Columbia Press, Vancouver.

Ceballos, G., and P. R. Ehrlich. 2002. Mammal population losses and the extinction crisis. Science 296:904-907.

Crandall, K. A., O. R. P. Bininda-Emonds, G. M. Mace, and R. K. Wayne. 2000. Considering evolutionary processes in conservation biology. Trends in Ecology \& Evolution 15:290-295.

Dauble, D. D., R. L. Johnson, and A. P. Garcia. 1999. Fall Chinook salmon spawning in the tailraces of Lower Snake River hydroelectric projects. Transactions American Fisheries Society 128:672-679.

Ehrlich, P. R., and G. C. Daily. 1993. Population extinction and saving biodiversity. Ambio 22:64-68.

Hampton, S. E., P. Romare, and D. E. Seiler. 2006. Environmentally controlled Daphnia spring increase with implications for sockeye salmon fry in Lake Washington, USA. Journal of Plankton Research 28:399-406.

Healey, M. C., and A. Prince. 1995. Scales of variation in life history tactics of Pacific salmon and the conservation of phenotype and genotype. American Fisheries Society Symposium 17:176-184.

Hilborn, R., T. P. Quinn, D. E. Schindler, and D. E. Rogers. 2003. Biocomplexity and fisheries sustainability. Proceedings of the National Academy of Sciences 100:6564-6568.

Hobbs, R. J., and H. A. Mooney. 1998. Broadening the extinction debate: population deletions and additions in California and Western Australia. Conservation Biology 12:271-283.

Houlahan, J. E., C. S. Findlay, B. R. Schmidt, A. H. Meyer, and S. L. Kuzmin. 2000. Quantitative evidence for global amphibian population declines. Nature 404:752-755.

Hughes, J. B., G. C. Daily, and P. R. Ehrlich. 1997. Population diversity: its extent and extinction. Science 278:689-692.

Leopold, A. 1953. Round River: from the journals of Aldo Leopold. Oxford University Press, Oxford, United Kingdom.

Lindley, S. T., et al. 2004. Population structure of threatened and endangered Chinook salmon ESUs in California's Central Valley basin. Technical memorandum NMFS-SWFSC-360. National Marine Fisheries Service, Southwest Fisheries Science Center, Santa Cruz, California.

Lindley, S. T., et al. 2006. Historical population structure of Central Valley steelhead and its alteration by dams. San Francisco Estuary and Watershed Science: http://repositories.cdlib.org/jmie/sfews/vol4/ iss1/art3.

Marr, J. C. 1943. Age, length, and weight studies of three species of Columbia River salmon (Oncorbynchus keta, O. gorbuscha, and $O$. kisutch). Stanford Ichthyological Bulletin 2:157-197.

McElhany, P., M. H. Ruckelshaus, M. J. Ford, T. C. Wainwright, and E. P. Bjorkstedt. 2000. Viable salmonid populations and the recovery of evolutionarily significant units. Technical memorandum NMFSNWFSC-42. National Marine Fisheries Service, Northwest Fisheries Science Center, Seattle, Washington.

McElhany, P., et al. 2006. Revised viability criteria for salmon and steelhead in the Willamette and Lower Columbia Basins, review draft. Available from http://www.nwfsc.noaa.gov/trt/wlc_docs/Revised_ WLC_Viability_Criteria_Draft_Apr_2006.pdf (accessed October 2006).

Mote, P. W. 2003a. Trends in temperature and precipitation in the Pacific Northwest during the twentieth century. Northwest Science 77:271-282.

Mote, P. W. 2003b. Twentieth-century fluctuations and trends in temperature, precipitation, and mountain snowpack in the Georgia BasinPuget Sound region. Canadian Water Resources Journal 28:567-586.

Myers, J. M., et al. 1998. Status review of Chinook salmon from Washington, Idaho, Oregon, and California. Technical memorandum NMFSNWFSC-35. National Marine Fisheries Service, Northwest Fisheries Science Center, Seattle, Washington.

Myers, J., C. Busack, D. Rawding, A. Marshall, D. Teel, D. M. Van Doornik, and M. T. Maher. 2006. Historical population structure of
Pacific salmonids in the Willamette River and Lower Columbia River basins. Technical memorandum NMFS-NWFSC-73. National Marine Fisheries Service, Northwest Fisheries Science Center, Seattle.

National Marine Fisheries Service (NMFS). 1997. Status review update for West Coast steelhead from Washington, Idaho, Oregon, and California. Memorandum ( 7 July) from the Biological Review Team to the National Marine Fisheries Service Northwest Regional Office. NMFS, Seattle. Available from http://www.nwr.noaa.gov/Publications/ Biological-Status-Reviews/upload/SR1997-steelhead1.pdf (accessed June 2006).

National Research Council. 1996. Upstream: salmon and society in the Pacific Northwest. National Academy Press, Washington, D.C.

Nehlsen, W., J. E. Williams, and J. A. Lichatowich. 1991. Pacific salmon at the crossroads: stocks at risk from California, Oregon, Idaho, and Washington. Fisheries 16:4-21.

Pauly, D. 1995. Anecdotes and the shifting baseline syndrome of fisheries. Trends in Ecology \& Evolution 10:430.

Peterson, J. H., and J. F. Kitchell. 2001. Climate regimes and water temperature changes in the Columbia River: bioenergetic implications for predators of juvenile salmon. Canadian Journal of Fisheries and Aquatic Sciences 58:1831-1841.

Quinn, T. P., and D. J. Adams. 1996. Environmental changes affecting the migratory timing of American shad and sockeye salmon. Ecology 77:1151-1162.

Quinn, T. P., S. Hodgson, and C. Peven. 1997. Temperature, flow, and the migration of adult sockeye salmon (Oncorbynchus nerka) in the Columbia River. Canadian Journal of Fisheries and Aquatic Sciences 54:1349-1360.

Ruckelshaus, M. H., K. P. Currens, W. H. Graeber, R. R. Fuerstenberg, K. Rawson, N. J. Sands, and J. B. Scott. 2006. Independent populations of Chinook salmon in Puget Sound. Technical memorandum NMFSNWFSC-78. National Marine Fisheries Service, Northwest Fisheries Science Center, Seattle.

Schluter, D., and L. M. Nagel. 1995. Parallel speciation by natural selection. The American Naturalist 146:292-301.

Small, M. P., T. D. Beacham, R. E. Withler, and R. J. Nelson. 1998. Discriminating coho salmon (Oncorbynchus kisutch) populations within the Fraser River, British Columbia, using microsatellite DNA markers. Molecular Ecology 7:141-155.

Taylor, E. B., C. J. Foote, and C. C. Wood. 1996. Molecular genetic evidence for parallel life-history evolution within a Pacific salmon (sockeye salmon and kokanee, Oncorbynchus nerka). Evolution 50:401416.

Thomas, J. A., M. G. Telfer, D. B. Roy, C. D. Preston, J.J.D. Greenwood, J. Asher, R. Fox, R. T. Clarke, and J. H. Lawton. 2004. Comparative losses of British butterflies, birds, and plants and the global extinction crisis. Science 303:1879-1881.

Thompson, J. D. 1991. Phenotypic plasticity as a component of evolutionary change. Trends in Ecology \& Evolution 6:246-249.

Waples, R. S. 1991. Pacific salmon, Oncorbynchus spp., and the definition of "species" under the Endangered species act. Marine Fisheries Review 53:11-22.

Waples, R. S. 1995. Evolutionarily significant units and the conservation of biological diversity under the Endangered species act. American Fisheries Society Symposium 17:8-27.

Waples, R. S., et al. 2001. Characterizing diversity in salmon from the Pacific Northwest. Journal of Fish Biology 59(Suppl. A):1-41.

Waples, R. S., D. J. Teel, J. M. Myers, and A. R. Marshall. 2004. Life-history divergence in Chinook salmon: historic contingency and parallel evolution. Evolution 58:386-403.

Weitkamp, L. A., T. C. Wainwright, G. J. Bryant, G. B. Milner, D. J. Teel, R. G. Kope, and R. S. Waples. 1995. Status review of coho salmon from Washington, Oregon, and California. Technical memorandum NMFSNWFSC-24. National Marine Fisheries Service, Northwest Fisheries Science Center, Seattle.

Welch, D. W., Y. Ishida, and K. Nagasawa. 1998. Thermal limits and 
ocean migrations of sockeye salmon (Oncorbynchus nerka): longterm consequences of global warming. Canadian Journal of Fisheries and Aquatic Sciences 55:937-948.

Williams, J. E., and C. D. Williams. 1991. The Sacramento River winter Chinook salmon threatened with extinction. Pages 105-115 in A. Lufkin, editor. California's salmon and steelhead trout: the struggle to restore an imperiled resource. University of California Press, Berkeley.

Williams, T. H., et al. 2006. Historical population structure of coho salmon in the Southern Oregon/Northern California Coasts Evo- lutionarily Significant Unit. Technical memorandum NMFS-SWFSC390. National Marine Fisheries Service, Southwest Fisheries Science Center, Santa Cruz, California.

Withler, F. C. 1982. Transplanting Pacific salmon. Canadian Technical Report of Fisheries and Aquatic Sciences 1079:1-27.

Wood, C. C. 1995. Life history variation and population structure in sockeye salmon. American Fisheries Society Symposium 17:195214.

Zar, J. H. 1999. Biostatistical analysis. 4th edition. Prentice Hall, Upper Saddle River, New Jersey.

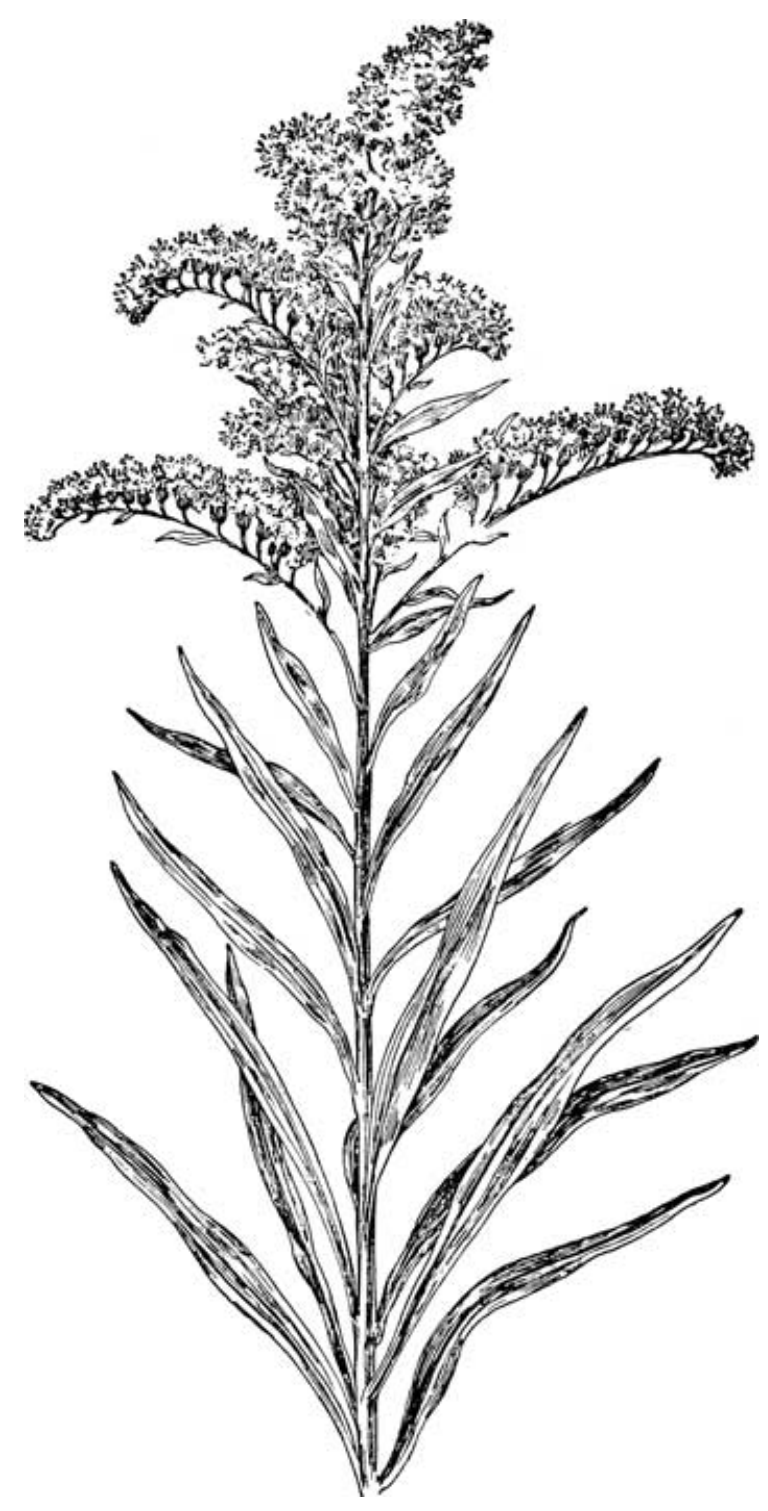

